\title{
Оценка современного состояния почвенного покрова Верхнебалкарского ущелья
}

\author{
Х-М. М. Газаев ${ }^{1}$, Л. С. Мурзамуратова ${ }^{1} \bowtie$, Ф. А. Атабиева ${ }^{1}$, Л. З. Жинжакова ${ }^{2}$ \\ ${ }^{1}$ Кабардино-Балкарский высокогорный государственный природный заповедник, Российская Федераџия \\ (61800, n. Kашхатау, Черекский р-н, Кабардино-Балкарская республика, ул. Мечиева, 78) \\ ${ }^{2}$ Высокогорный геофизический институт, Российская Федераџия \\ (360030, г. Нальчик, Кабардино-Балкарская республика, пр. Ленина, 2) \\ Поступила в редакиию 5.06 .19 \\ Принята к публикаичи 26.02.2020
}

\begin{abstract}
Аннотация: В настоящее время остается все меньше ненарушенных эталонных почв и в связи с этим все большее значение приобретают почвы заповедников, остающиеся относительно нетронутыми и выступающими в качестве эталонов.

Исследование почв Кабардино-Балкарского государственного заповедника рассматривается как система наблюдений в пространстве и времени, дающая информацию о состоянии почвенного покрова.

Горные почвы территории Кабардино-Балкарского государственного заповедника, а именно Верхнебалкарского ущелья, изучены недостаточно, поэтому иелью исследования явилась организация изучения характеристик почвенного покрова и осуществление в будущем программы почвенного мониторинга фоновых территорий в заповеднике. Исследуемый участок расположен в верховьях правого берега реки Черек Балкарский на территории заповедника и частично в его охранной зоне.

При изучении почвенных характеристик применялись полевые и аналитико-сравнительные методы исследования. Почвенные характеристики изучались в почвенном разрезе, имевшем глубину 0-3 см, 3-16 см и ниже до почвообразующей породы. Образцы отбирались под различной растительностью: смешанный лес, ольшаник, ивняк, кустарники семейства березовых и луг.

На каждом ключевом участке отбирали почву в горизонтах А и В, где определялись показатели, характеризующие состояние почв: глубина взятия пробы, мощность гумусового слоя, $\mathrm{pH}_{\text {води }}, \mathrm{pH}_{\text {солевой' }}$ обменная кислотность, ионы $\mathrm{Ca}^{2+}$ и $\mathrm{Mg}^{2+}, \mathrm{SO}_{4}^{-}, \mathrm{Cl}^{-}$. Общим свойством почв является незначительная выраженность горизонтов, укороченность почвенного профиля, наличие мелких камней различного диаметра, а ниже слабого гумусового слоя более крупных каменных включений. Почвенный разрез удалось пройти всего на 10-13 см, ниже лежит плотный слой мелкообломочного материала, в который по трещинам и промежуткам между камнями проникает почва.

Результаты исследований почв на содержание сульфат-, хлорид-, кальций-, магний-ионов показали, что максимально высокая концентрация серосодержащего компонента почвы, равная 68,16 мг/кг, отмечалось в слое 0-3 см лесной почвы. Концентрация хлора достаточно высокая в верхних слоях почвы и составляет 15,98-31,95 мг/кг. Меньше во втором слое в луговых почвах (3,9-6,4 мг/кг), а в горизонте В лесной почвы его содержание увеличилось почти в 3 раза (от 30,2 до 88,75), что говорит о тенденции накопления хлора в нижнем слое. Содержание кальция и магния в лесных почвах выше, как в горизонте А, так и в горизонте В, по сравнению с луговыми почвами.

Полученные показатели являются фоновыми и могут иметь значение при анализе общих закономерностей и региональных особенностей структуры почв, а также для получения количественных оценок связи между компонентами почвы.
\end{abstract}

Ключевые слова: почвенный покров, морфология, физико-химические свойства почв, Верхнебалкарское ущелье, особо охраняемая территория.

(ㄱ Газаев Х-М.М., Мурзамуратова Л.С., Атабиева Ф. А., Жинжакова Л.3., 2020

$\triangle$ E-mail: luki-786.90@mail.ru

() () Контент доступен под лицензией Creative Commons Attribution 4.0 License.

The content is available under Creative Commons Attribution 4.0 License. 


\title{
Assessment of the Current State of the Soil Cover of the Verkhnebalkarsky Gorge
}

\author{
H.-M. M. Gazaev, L. S. Murzamuratova $\bowtie$, F. A. Atabieva, L. Z. Jinjakova
}

\begin{abstract}
At present, there are fewer undisturbed reference soils and in this regard, it is becoming increasingly important soil reserves, remaining relatively intact and acting as references. The study of soil KabardinoBalkar State Reserve is considered as an observing system in space and time, giving information about the state of the soil cover. Mountain soils the territory of Kabardino-Balkarsky state nature reserve, namely Verkhnebalkarsky gorge has been insufficiently studied, so the aim of the study was the organization of the study characteristics of the soil cover of the area and the future implementation of the soil monitoring programme background areas in the reserve. Study area the soil cover is located in the upper reaches of the right Bank of the Cherek-Balkarsky River on the territory of Kabardino-Balkar High-Mountain State Nature Reserve and partly in the protected zone. Selected sites for more information about the initial state of the soil, as for this purpose selected the most typical for this region of the soil landscapes and soil. Soil characteristics were studied in the soil section, having a depth of $0-3 \mathrm{~cm}, 3-16 \mathrm{~cm}$ and below to the parent rocks. Soils were sampled under different vegetation: mixed forest, alder, willow, shrubs in the family birch and meadow.

In each of the items selected soil horizons $\mathrm{A}$ and $\mathrm{B}$, where the determined parameters characterizing the soil: depth of sampling, the humus layer, $\mathrm{pH}_{\text {water }}, \mathrm{pH}_{\text {salt }}$, acidity, ions $\mathrm{Ca}^{2+}$ and $\mathrm{Mg}^{2+}, \mathrm{SO}_{4}^{-}, \mathrm{Cl}^{-}$. $\mathrm{A} \mathrm{common}^{2}$ property of soils is the low severity of horizons, shortening the soil profile, the presence of small stones of various diameters and below the weak humus layer of larger stone inclusions. The soil cut failed to pass by only $10-13 \mathrm{~cm}$, below is a dense layer small fragments material in which the cracks and gaps between the stones penetrates the soil.

The results of soil research on the content of sulfate-, chloride-, calcium-, magnesium-ions showed that the highest concentration of sulfur-containing component of the soil, the equal of $68.16 \mathrm{mg} / \mathrm{kg}$, was observed in the layer $0-3 \mathrm{~cm}$ of the forest soil. The concentration of chlorine is quite high in the upper layers of the soil and is $15.98-31.95 \mathrm{mg} / \mathrm{kg}$. Less chlorine is contained in the second layer in meadow soils (3.9-6.4 mg/kg), and in the horizon B in forest soil, its content has increased almost 3 times (from 30.2 to 88.75), which indicates a trend of accumulation of chlorine in the lower layer. The content of calcium and magnesium in forest soils is higher, both in horizon A and horizon B, compared to meadow soils. The obtained indicators are background and can be important for analyzing general patterns and regional features of soil structure, as well as for obtaining quantitative estimates of the relationship between soil components.
\end{abstract}

Key words: soil cover, morphology, physical-chemical properties of soils, Verkhnebalkarsky gorge, protected area.

\section{ВВЕДЕНИЕ}

Одним из основных условий рационального природопользования является деятельность, направленная на сохранение существующих фоновых почв и восстановление нарушенного почвенного покрова. В настоящее время остается все меньше ненарушенных эталонных почв и в связи с этим все большее значение приобретают почвы заповедников, остающиеся относительно нетронутыми и выступающими в качестве эталонов. Почвы являются производными пяти факторов: климата, материнской породы, рельефа, живых организмов и времени. Все различия в составе растительности, рельефа и горных пород влекут за собой изменения в свойствах почв [1-8]. Почвообразование в горах имеет целый ряд особенностей. При этом почвообразующие породы в горных районах практически не являются элювиями, а носят характер наносов [1]. Как следствие - почвы становятся более динамичными в смысле изменения своих свойств, которые приближаются к свойствам подстилающих горных пород. Таким образом, вклад каждого из пяти факторов почвообразователей в формировании свойств горных почв оказывается иным, чем при формировании равнинных почв. При этом на первый план выходят свойства горных пород и влияние элементов рельефа. Горные почвы имеют меньшую мощность почвенных профилей, значительную каменистость и постоянное или периодическое омоложение почвенных горизонтов, зависящее от интенсивности явлений эрозии.

Горные почвы Кабардино-Балкарского государственного заповедника, а именно Верхнебалкарского ущелья, изучены недостаточно. Главной целью исследования явилась организация и осуществление программы почвенного мониторинга. Исследуемый участок почвенного покрова расположен в верховьях реки Черек Балкарский на территории заповедника и частично в его охранной зоне. Выбранные ключевые участки предназначены для получения информации об исходном состоянии почв. 
Пункты отбора проб почвы

[Table 1. The sampling points of the soil

\begin{tabular}{|c|c|c|c|c|c|c|}
\hline \multirow[b]{2}{*}{ 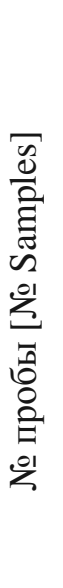 } & \multirow[b]{2}{*}{ 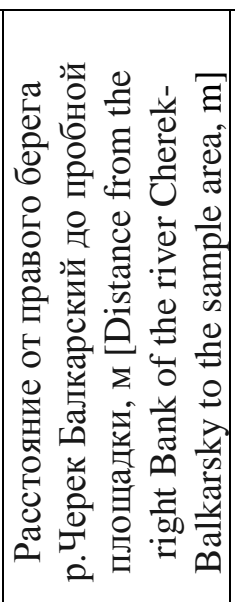 } & \multirow{2}{*}{$\begin{array}{l}\text { Растительный покров } \\
\text { исследуемой } \\
\text { территории [The } \\
\text { vegetation cover of the } \\
\text { study area] }\end{array}$} & \multicolumn{2}{|c|}{$\begin{array}{c}\text { Глубина взятия } \\
\text { образцов } \\
\text { [Depthofsampling] }\end{array}$} & \multirow[b]{2}{*}{ 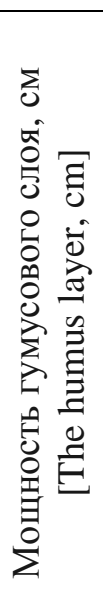 } & \multirow[b]{2}{*}{ 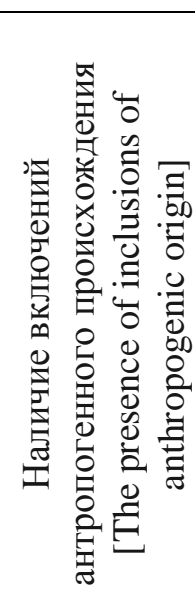 } \\
\hline & & & 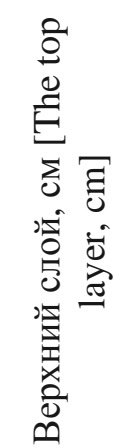 & 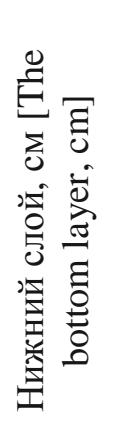 & & \\
\hline 1. & 20 & $\begin{array}{l}\text { Лес, ольшаник } \\
\text { [Forest, alder] }\end{array}$ & $0-3$ & $3-15$ & 3 & - \\
\hline 2. & 30 & $\begin{array}{l}\text { Лес, ольшаник } \\
\text { [Forest, alder] }\end{array}$ & $0-3$ & $3-15$ & $>10$ & - \\
\hline 3. & 40 & $\begin{array}{c}\text { Поляна, разнотравье } \\
\text { [Meadow, grass] }\end{array}$ & $0-3$ & $3-16$ & 3 & - \\
\hline 4. & 50 & $\begin{array}{c}\text { Лес, ивняк } \\
\text { [Forest, willow] }\end{array}$ & $0-3$ & $3-15$ & 5 & - \\
\hline 5. & 30 & $\begin{array}{l}\text { Лес, opешник } \\
\text { [Woods, hazel] }\end{array}$ & $0-10$ & 10 & 10 & - \\
\hline 6. & 20 & $\begin{array}{l}\text { Лес, ольшаник } \\
\text { [Forest, alder] }\end{array}$ & $0-5$ & 5 & 5 & - \\
\hline 7. & 30 & $\begin{array}{l}\text { Лес, opешник } \\
\text { [Woods, hazel] }\end{array}$ & $0-8$ & 8 & 8 & - \\
\hline 8. & 20 & $\begin{array}{l}\text { Поляна, разнотравье } \\
\text { [Meadow, grass] }\end{array}$ & $0-10$ & 10 & 10 & - \\
\hline
\end{tabular}

\section{МАТЕРИАЛ И МЕТОДЫ ИССЛЕДОВАНИЯ}

Для изучения некоторых почвенных показателей в июне и сентябре 2008 года были выбраны три пункта отбора летом и пять пунктов в сентябре на правом берегу реки Черек Балкарский. Почвенные характеристики изучались в почвенном разрезе, имевшем глубину 0-3 cм, 3-16 см и ниже до почвообразующей породы. Образцы почвы отбирались под различной растительностью: смешанный лес, ольшаник, ивняк, кустарники семейства березовых и луг (таблица 1). Почва правого берега реки Черек Балкарский относится к горным лесолуговым. Преобладающий механический состав почвы - легкосуглинистый.

Отбор и анализ почвы проводили по существующим стандартным методикам:

ГОСТ - 17.4.4.02-84. Охрана природы. Почвы. Методы отбора и подготовки проб для химичес- кого, бактериологического, гельминтологического анализа;

ГОСТ - 26423-85. Почвы. Методы определения удельной электрической проводимости, $\mathrm{pH}$ и плотного остатка водной вытяжки;

ГОСТ - 26483-85. Почвы. Приготовление солевой вытяжки и определение ее рН по методу ЦИ$\mathrm{HAO}$

ГОСТ - 26484-85. Почвы. Метод определения обменной кислотности;

ГОСТ - 26428-85. Почвы. Методы определения кальция и магния в водной вытяжке;

ГОСТ - 26426-85. Почвы. Методы определения иона сульфата в водной вытяжке;

ГОСТ - 26425-85. Почвы. Методы определения иона хлорида в водной вытяжке.

Размещение пунктов отбора почвы осуществлялось так, чтобы равномерно охватить изучаемую 
территорию. В каждом из пунктов отбирали почву в горизонтах А и В, где определялись показатели, характеризующие состояние почв: глубина взятия пробы, мощность гумусового слоя, рНводн, pНсолевой, обменная кислотность, $\mathrm{Ca}^{2+}$ и $\mathrm{Mg}^{2+}$, $\mathrm{SO}_{4}^{-}, \mathrm{Cl}^{-}$. Эти показатели были условно сгруппированы в два блока: морфологический и физикохимический.

Выбранные пункты отбора почв отвечают требованиям, предъявляемым к пунктам фонового мониторинга, и в достаточной мере отражают типичные особенности исследуемой территории. При аналитической обработке материалов по почвам, нами был использован метод А.А. Роде. Метод заключается в сравнении вещественного состава и свойств твердой фазы почвенных горизонтов, с одной стороны, и материнской породы - с другой (минералогического и химического составов, органического вещества, почвенных растворов, воздуха, почвенных животных и микроорганизмов).

\section{РЕЗУЛЬТАТЫ И ИХ ОБСУЖДЕНИЕ}

Полученные результаты представлены в таблицах 2, 3, 4.

По величине $\mathrm{pH}$ лесная почва верхнего пункта (п. 1) и луговая почва (п. 3) характеризуются как нейтральные и варьируют в пределах 7,1-7,2 pH. Почва (п. 2), отобранная в лесу, носит слабокислый характер. Нижние горизонты летних образцов почв относятся к слабо кислым и кислым, а величина рН изменялась от 6,95 до 5,55.

Почвы осеннего отбора изменялись от 5,95 до 7,25 . При этом в верхнем слое почвы от 6,0 до $6,9 \mathrm{pH}$, а в нижнем от 6,1 до 7,25. В целом исследованные почвы летнего и осеннего периодов носят слабокислую реакцию.

Данные по обменной кислотности представленные в таблице 2 свидетельствуют о том, что она изменяется от 1,05 до 1,30 раза в верхнем слое почвы и от 1,05 до 1,40 раза в нижнем горизонте.

Общим свойством почв является незначительная выраженность горизонтов, укороченность по-

Таблиия 2

Морфологические и физические показатели почв, отобранных на правом берегу р. Черек Балкарский [Table 2. Morphological and physical characteristics of soils sampled on the right Bank Cherek-Balkarsky River]

\begin{tabular}{|c|c|c|c|c|c|}
\hline \multirow[t]{2}{*}{ № } & \multirow{2}{*}{$\begin{array}{c}\text { Пункты отбора почв/ } \\
\text { [Points of selection of soil] }\end{array}$} & \multirow{2}{*}{$\begin{array}{c}\text { Мощность } \\
\text { гумус. слоя, } \\
\text { см / } \\
\text { [The power } \\
\text { of humus } \\
\text { layer] }\end{array}$} & \multicolumn{3}{|c|}{$\begin{array}{c}\text { Концентрация водородных } \\
\text { ионов почвы, ед. } \\
\text { [The hydrogen ion concentrations } \\
\text { of the soil units] }\end{array}$} \\
\hline & & & $\begin{array}{l}\mathrm{pH}_{\text {воднн }} / \\
{\left[\mathrm{pH}_{\text {water }}\right]}\end{array}$ & $\begin{array}{l}\mathrm{pH}_{\text {солевой/ }} \\
{\left[\mathrm{pH}_{\text {saline }}\right]}\end{array}$ & $\begin{array}{c}\text { Обменная } \\
\text { кислотность } \\
\text { [Acidity] }\end{array}$ \\
\hline 1 & 2 & 3 & 4 & 5 & 6 \\
\hline 1. & $\begin{array}{l}\text { Правый берег р.Черек } \\
\text { Балкарский, } 9 \text { км от с. В.- } \\
\text { Балкария, 60м от берега, лес, } \\
\text { верхний слой 0-3 см, } \\
\text { нижний слой - } 3-15 \mathrm{~cm} \\
\text { [The right Bank of the river } \\
\text { Cherek-Balkarsky, } 9 \mathrm{~km} \text { from } \mathrm{S} \text {. } \\
\text { V.-Balkaria, } 60 \mathrm{~m} \text { from the beach, } \\
\text { the forest, } \\
\text { the upper layer 0-3 cm, } \\
\text { the lower layer is } 3-15 \mathrm{~cm} \text { ] }\end{array}$ & $3 \mathrm{~cm}$ & $\begin{array}{l}7,10 \\
5,95\end{array}$ & $\begin{array}{l}6,25 \\
5,00\end{array}$ & $\begin{array}{l}1,14 \\
1,19\end{array}$ \\
\hline 2. & $\begin{array}{l}\text { Правый берег } \\
\text { р.Черек Балкарский, } 6 \text { км от с.В.- } \\
\text { Балкария, 30м от берега, лес, } \\
\text { верхний слой 0-3 см, } \\
\text { нижний слой } 3-15 \mathrm{~cm} \text { [The right } \\
\text { Bank } \\
\text { R. Cherek-Balkarsky, } 6 \mathrm{~km} \text { from } \mathrm{S} \text {. } \\
\text { V.-Balkaria, } 30 \mathrm{~m} \text { from the beach, } \\
\text { the forest, } \\
\text { the upper layer } 0-3 \mathrm{~cm}, \\
\text { the lower layer is } 3-15 \mathrm{~cm}]\end{array}$ & $>10 \mathrm{~cm}$ & $\begin{array}{l}6,25 \\
5,55\end{array}$ & $\begin{array}{l}5,35 \\
4,65\end{array}$ & $\begin{array}{l}1,05 \\
1,20\end{array}$ \\
\hline
\end{tabular}


Продолжение таблицьь 2 / [Table 2 (continued)]

\begin{tabular}{|c|c|c|c|c|c|}
\hline 1 & 2 & 3 & 4 & 5 & 6 \\
\hline 3. & $\begin{array}{l}\text { Правый берег } \\
\text { р.Черек Балкарский, } 3 \text { км от с.В.- } \\
\text { Балкария, 40м от берега, луг. } \\
\text { верхний слой 0-3 см, } \\
\text { нижний слой } 3-15 \text { см [The right } \\
\text { Bank } \\
\text { R. Cherek-Balkarsky, } 6 \mathrm{~km} \text { from } \mathrm{S} \text {. } \\
\text { V.-Balkaria, } 30 \mathrm{~m} \text { from the beach, } \\
\text { the forest, } \\
\text { the upper layer } 0-3 \mathrm{~cm}, \\
\text { the lower layer is } 3-15 \mathrm{~cm} \text { ] }\end{array}$ & $3 \mathrm{~cm}$ & $\begin{array}{l}7,20 \\
6,95\end{array}$ & $\begin{array}{l}6,60 \\
6,00\end{array}$ & $\begin{array}{l}1,09 \\
1,16\end{array}$ \\
\hline 4. & $\begin{array}{l}\text { Исходная точка -9 км от с. В.- } \\
\text { Балкария, } 20 \text { м от берега, лес, } \\
\text { верхн. слой, 0-3 см, } \\
\text { нижний слой - } 3-16 \text { см [Starting } \\
\text { point - } 9 \mathrm{~km} \text { from } \mathrm{S} \text {. V.-Balkaria, } \\
20 \mathrm{~m} \text { from the shore, the woods, } \\
\text { top. layer, 0-3 cm, } \\
\text { the bottom layer } 3-16 \mathrm{~cm}]\end{array}$ & $5 \mathrm{~cm}$ & $\begin{array}{l}6,80 \\
6,50\end{array}$ & $\begin{array}{l}6,10 \\
6,15\end{array}$ & $\begin{array}{l}1,11 \\
1,05\end{array}$ \\
\hline 5. & $\begin{array}{l}8,1 \text { км от с. В.-Балкария, } 20 \text { м от } \\
\text { берега, лес } \\
\text { верхн. слой, } 0-10 \text { см, } \\
\text { нижний слой } 10 \mathrm{~cm}[8.1 \mathrm{~km} \text { from } \\
\mathrm{S} . \text { V.-Balkaria, } 20 \mathrm{~m} \text { from the } \\
\text { shore, forest } \\
\text { top. layer, } 0-10 \mathrm{~cm} \text {, } \\
\text { the lower layer } 10 \mathrm{~cm}]\end{array}$ & $10 \mathrm{~cm}$ & $\begin{array}{l}5,95 \\
6,10\end{array}$ & $\begin{array}{l}4,55 \\
4,35\end{array}$ & $\begin{array}{l}1,30 \\
1,40\end{array}$ \\
\hline 6. & $\begin{array}{l}\text { 7,3 км от с. В.-Балкария, } 20 \text { м от } \\
\text { берега, лес, } \\
\text { верхн. слой - } 0-5 \text { см, } \\
\text { нижний слой } 5 \text { см [7.3 km from S. } \\
\text { V. - Balkaria, } 20 \mathrm{~m} \text { from the shore, } \\
\text { the woods, } \\
\text { top. layer - 0-5 cm, } \\
\text { the bottom layer is } 5 \mathrm{~cm}]\end{array}$ & $5 \mathrm{~cm}$ & $\begin{array}{l}6,90 \\
6,10\end{array}$ & $\begin{array}{l}6,00 \\
4,65\end{array}$ & $\begin{array}{l}1,15 \\
1,31\end{array}$ \\
\hline 7. & $\begin{array}{l}5,7 \text { км от с. В.- Балкария, } 50 \text { м от } \\
\text { берега, лес, } \\
\text { верхн. слой - } 0-8 \text { см. } \\
\text { нижний слой } 8 \text { см [5.7 km from S. } \\
\text { V. - Balkaria, } 50 \mathrm{~m} \text { from the shore, } \\
\text { the woods, } \\
\text { top. layer } 0-8 \mathrm{~cm} \\
\text { the bottom layer is } 8 \mathrm{~cm}]\end{array}$ & $8 \mathrm{~cm}$ & $\begin{array}{l}6,45 \\
6,35\end{array}$ & $\begin{array}{l}5,20 \\
4,65\end{array}$ & $\begin{array}{l}1,24 \\
1,36\end{array}$ \\
\hline 8. & $\begin{array}{l}3,7 \text { км от с. В.-Балкария, } 30 \text { м от } \\
\text { берега, луг, } \\
\text { верхн. слой - } 0-10 \text { см. } \\
\text { нижний слой } 10 \text { см [3.7 km from } \\
\mathrm{S} . \mathrm{V} . \text { - Balkaria, } 30 \mathrm{~m} \text { from the } \\
\text { shore, the meadow, } \\
\text { top. the layer } 0-10 \mathrm{~cm} \\
\text { the lower layer } 10 \mathrm{~cm}]\end{array}$ & $10 \mathrm{~cm}$ & $\begin{array}{l}6,50 \\
7,25\end{array}$ & $\begin{array}{l}5,40 \\
6,45\end{array}$ & $\begin{array}{l}1,20 \\
1,12\end{array}$ \\
\hline
\end{tabular}


Химические показатели почв, отобранных на правом берегу р. Черек Балкарский [Table 3. Chemical characteristics of soils sampled on the right Bank of the Cherek Balkarsky River]

\begin{tabular}{|c|c|c|}
\hline \multirow[t]{2}{*}{ Пункты отбора почв [Points of selection of soil] } & \multicolumn{2}{|c|}{$\begin{array}{c}\text { Концентрация поглощенного Са и } \\
\text { Mg по Тюрину, мг-экв } \\
\text { [The concentration of absorbed CA } \\
\text { and Mg by Tyurin, mg-equi.] }\end{array}$} \\
\hline & $\mathrm{Ca}^{2+}$ & $\mathrm{Mg}^{2+}$ \\
\hline $\begin{array}{l}\text { Правый берег р.Черек Балкарский, } 9 \text { км от с. } \\
\text { В.Балкария, } 60 \text { м от берега, луг. } \\
\text { Верхний слой, 0-3 см } \\
\text { Нижний слой } 3-15 \text { см } \\
\text { [The right Bank of the river Cherek-Balkarsky, } 9 \mathrm{~km} \\
\text { from S. V. Balkaria, } 60 \mathrm{~m} \text { from the shore, the meadow. } \\
\text { The top layer, 0-3 cm } \\
\text { The lower layeris } 3-15 \mathrm{~cm} \text { ] }\end{array}$ & $\begin{array}{l}2,00 \\
1,59\end{array}$ & $\begin{array}{l}0,40 \\
0,80\end{array}$ \\
\hline $\begin{array}{l}\text { Правый берег р.Черек Балкарский, } 6 \text { км от с. } \\
\text { В.Балкария, 30м от берега, лес. } \\
\text { Верхний слой, 0-3 см } \\
\text { Нижний слой } 3-15 \text { см } \\
\text { [The right Bank of the river Cherek-Balkarsky, } 6 \mathrm{~km} \\
\text { from S. V. Balkaria, } 30 \mathrm{~m} \text { from the shore, the forest. } \\
\text { The top layer, } 0-3 \mathrm{~cm} \\
\text { The lower layeris } 3-15 \mathrm{~cm} \text { ] }\end{array}$ & $\begin{array}{l}4,00 \\
5,90\end{array}$ & $\begin{array}{l}1,60 \\
2,90\end{array}$ \\
\hline $\begin{array}{l}\text { Правый берег р.Черек Балкарский, } 3 \text { км от с. } \\
\text { В.Балкария, 40м от берега, луг. } \\
\text { Верхний слой, 0-3 см } \\
\text { Нижний слой } 3-15 \text { см } \\
\text { [The right Bank of the river Cherek-Balkarsky, } 3 \mathrm{~km} \\
\text { from C. V. s, 40m from the shore, the meadow. } \\
\text { The top layer, 0-3 cm } \\
\text { The lowe rlayeris } 3-15 \mathrm{~cm} \text { ] }\end{array}$ & $\begin{array}{l}2,40 \\
2,00\end{array}$ & $\begin{array}{l}0,40 \\
0,80\end{array}$ \\
\hline
\end{tabular}

чвенного профиля, наличие мелких камней различного диаметра, а ниже слабого гумусового слоя более крупных каменных включений. Почвенный разрез удалось пройти всего на 10-13 см, так как ниже лежит плотный слой мелкообломочного материала, в который по трещинам и промежуткам между камнями проникают следы почвы. Весь разрез (п.1 и п.3) представлен гумусовым горизонтом супесчаным, сверху слегка оглиненные. Почвы структурированы, горно-черноземного типа, не карбонатные.

Лесной ландшафт (п. 2) расположен в 6 км от села В.-Балкария. В почвенном покрове здесь различаются два слоя: слой лесной подстилки из неразложившихся и полуразложившихся листьев, мха, ветоши и гумусово-аккумулятивный горизонт. Карбонаты в почвах отсутствуют.

Образец лесной почвы (п. 2) отличается от луговых почв с открытой местности, как в верхнем, так и в нижнем слое. Особенностью лесной почвы является гумусовый слой. Морфологическое строение профиля почвы, отобранной в лесу в верхнем слое 0-3 см отличается от верхних слоев луговых почв. Во втором слое почва леса влажная, буровато-черная, черноземовидная, непрочно-комковатая структура, слабо уплотненная.

Образцы почв пунктов 1 и 3 типичные горные луговые серовато-бурые суглинистые, непрочнокомковатые по структуре, слабо уплотненные, включение камней до 10-12\%, переход от горизонта к горизонту постепенный, но выраженный, а нижний слой составляет всего 13 см и 10 см соответственно.

Установлены типичные для исследуемой территории в летний период концентрации кальция и магния. Установлено их распределение по почвенным горизонтам. Пункты летнего отбора почвы на анализ располагались на правом берегу реки Че- 
рек Балкарский. Первый пункт (п. 1) находился в 9 км от села В.-Балкария у самой реки на открытой местности, второй (п. 2) - в 6 км от села В.Балкария в лесу, а третий (п. 3) - на лугу в 3 км от села В.-Балкария (таблица 3).

В таблице 3 представлены данные поглощенного кальция и магния. В пунктах 1 и 3 (луговые почвы) показатель поглощенного магния в верхнем и нижнем слоях один и тот же, а поглощенный кальций несколько ниже в первом пункте отбора. Эта количественная составляющая для лесной почвы отличается по обоим горизонтам по $\mathrm{Ca}^{2+}$ и $\mathrm{Mg}^{2+}$. Количество поглощенного кальция во всех исследованных образцах почв в несколько раз выше, чем количество магния, при этом в верхнем слое сосредоточено от 2,5 до 6 раз, а в нижнем слое в 2 раза.

Кальций и магний. Результаты анализа показывают, что в верхних горизонтах почв (0-3 см) аккумулируется значительное количество серы, хлоpa, а также кальция (таблица 4).
Из минералов класса сульфатов наиболее распространены гипс $\mathrm{CaSO}_{4}$ гидратный, полугидратный иногда ангидрит. Концентрация $\mathrm{Ca}^{2+}$ изменяется от 40,08 до 92,8 мг/кг и от 32 до 120 мг/кг соответственно в верхнем и нижнем слое почвы. Как видим из таблицы 4 содержание кальция и магния в лесных почвах выше, как в горизонте A, так и в горизонте В. Накопление этих элементов во втором слое лесной почвы выше в 1-2 раза, чем в луговых. В слабо гумусированных почвах накопление щелочноземельных элементов ниже, что связано с промывным характером почв. Концентрация $\mathrm{Mg}^{2+}$ во всех исследованных образцах почв намного ниже кальция, но его накопление во втором слое также обнаружено.

Сульфаты. Известно, что сульфаты лучше всего закрепляются на сухих почвах, и как оказалось, именно в луговых образцах его содержание было несколько выше, как в слое $0-3$ см (0-5 см), так и в слое $16-16$ см. В луговой почве, которая много суше двух остальных наблюдается накопление сульфа-

Концентрация некоторых почвенных показателей с исследуемой территории

[Table 4. The concentration of some soil parameters with the study area]

\begin{tabular}{|c|c|c|c|c|c|c|}
\hline \multirow[t]{2}{*}{ № } & \multirow[t]{2}{*}{$\begin{array}{c}\text { Пункты отбора почв } \\
\text { [Points of selection of soil] }\end{array}$} & \multirow[t]{2}{*}{$\begin{array}{l}\mathrm{pH}_{\text {водн }} \\
{\left[\mathrm{pH}_{\text {water }}\right]}\end{array}$} & \multicolumn{4}{|c|}{$\begin{array}{l}\text { Концентрация водорастворимых ионов почвы, } \\
\text { мг/кг } \\
\text { [the concentration of water soluble ions of the soil, } \\
\mathrm{mg} / \mathrm{kg} \text { ] }\end{array}$} \\
\hline & & & $\mathrm{Ca}^{2+}$ & $\mathrm{Mg}^{2+}$ & $\mathrm{SO}_{4}^{-}$ & $\mathrm{Cl}^{-}$ \\
\hline 1 & 2 & 3 & 4 & 5 & 6 & 7 \\
\hline 1. & $\begin{array}{l}\text { Правый берег р.Черек } \\
\text { Балкарский, } 9 \text { км от с. В.- } \\
\text { Балкария, 60м от берега, лес, } \\
\text { верхний слой 0-3 см, } \\
\text { нижний слой - } 3-15 \mathrm{~cm} \\
\text { [The right Bank of the river } \\
\text { Cherek-Balkarsky, } 9 \mathrm{~km} \text { from S. } \\
\text { V.-Balkaria, } 60 \mathrm{~m} \text { from the beach, } \\
\text { the forest, } \\
\text { the upper layer } 0-3 \mathrm{~cm}, \\
\text { the lower layer is } 3-15 \mathrm{~cm} \text { ] }\end{array}$ & $\begin{array}{l}7,10 \\
5,95\end{array}$ & $\begin{array}{l}40,1 \\
32,0\end{array}$ & $\begin{array}{l}4,86 \\
9,72\end{array}$ & $\begin{array}{l}50,4 \\
0,00\end{array}$ & $\begin{array}{l}32 \\
3,9\end{array}$ \\
\hline 2. & $\begin{array}{l}\text { Правый берег } \\
\text { р.Черек Балкарский, } 6 \text { км от } \\
\text { с.В.-Балкария, 30м от берега, } \\
\text { лес, } \\
\text { верхний слой } 0-3 \mathrm{cm,} \\
\text { нижний слой } 3-15 \mathrm{~cm} \text { [The right } \\
\text { Bank R. Cherek-Balkarsky, } 6 \text { km } \\
\text { from S. V.-Balkaria, } 30 \mathrm{~m} \text { from } \\
\text { the beach, the forest, } \\
\text { the upper layer 0-3 cm, } \\
\text { the lower layer is } 3-15 \mathrm{~cm}]\end{array}$ & $\begin{array}{l}6,25 \\
5,55\end{array}$ & $\begin{array}{l}80,2 \\
118\end{array}$ & $\begin{array}{l}19,4 \\
35,2\end{array}$ & $\begin{array}{l}68,2 \\
2,88\end{array}$ & $\begin{array}{l}30 \\
89\end{array}$ \\
\hline
\end{tabular}


Продолжение таблиць 4 / [Table 4 (continued)]

\begin{tabular}{|c|c|c|c|c|c|c|}
\hline 1 & 2 & 3 & 4 & 5 & 6 & 7 \\
\hline 3. & $\begin{array}{l}\text { Правый берег } \\
\text { р.Черек Балкарский, } 3 \text { км от } \\
\text { с.В.-Балкария, 40м от берега, } \\
\text { луг. } \\
\text { верхний слой 0-3 см, } \\
\text { нижний слой } 3-15 \text { см [The right } \\
\text { Bank R. Cherek-Balkarsky, } 6 \mathrm{~km} \\
\text { from S. V.-Balkaria, } 30 \mathrm{~m} \text { from } \\
\text { the beach, the forest, } \\
\text { the upper layer 0-3 cm, } \\
\text { the lower layer is } 3-15 \mathrm{~cm} \text { ] }\end{array}$ & $\begin{array}{l}7,20 \\
6,95\end{array}$ & $\begin{array}{l}48,1 \\
40,0\end{array}$ & $\begin{array}{l}4,86 \\
9,72\end{array}$ & $\begin{array}{l}57,6 \\
38,4\end{array}$ & $\begin{array}{l}16 \\
6,4\end{array}$ \\
\hline 4. & $\begin{array}{l}\text { Исходная точка - } 9 \text { км от с. В.- } \\
\text { Балкария, } 20 \text { м от берега, лес, } \\
\text { верхн. слой, 0-3 см, } \\
\text { нижний слой - 3-16 см [Starting } \\
\text { point - } 9 \mathrm{~km} \text { from S. V.-Balkaria, } \\
20 \mathrm{~m} \text { from the shore, the woods, } \\
\text { top. layer, 0-3 cm, } \\
\text { the bottom layer } 3-16 \mathrm{~cm} \text { ] }\end{array}$ & $\begin{array}{l}6,80 \\
6,50\end{array}$ & $\begin{array}{c}85,7 \\
102\end{array}$ & $\begin{array}{l}18,2 \\
34,4\end{array}$ & $\begin{array}{l}62,4 \\
5,18\end{array}$ & $\begin{array}{l}2,13 \\
1,60\end{array}$ \\
\hline 5. & $\begin{array}{l}8,1 \text { км от с. В.-Балкария, } 20 \text { м } \\
\text { от берега, лес } \\
\text { верхн. слой, } 0-10 \text { см, } \\
\text { нижний слой } 10 \text { см }[8.1 \mathrm{~km} \\
\text { from S. V.-Balkaria, } 20 \mathrm{~m} \text { from } \\
\text { the shore, forest } \\
\text { top. layer, } 0-10 \mathrm{~cm}, \\
\text { the lower layer } 10 \mathrm{~cm}]\end{array}$ & $\begin{array}{l}5,95 \\
6,10\end{array}$ & $\begin{array}{c}92,8 \\
114\end{array}$ & $\begin{array}{l}20,1 \\
42,3\end{array}$ & $\begin{array}{l}52,8 \\
10,7\end{array}$ & $\begin{array}{l}2,30 \\
1,70\end{array}$ \\
\hline 6. & $\begin{array}{l}\text { 7,3 км от с. В.- Балкария, } 20 \text { м } \\
\text { от берега, лес, } \\
\text { верхн. слой - 0-5 см, } \\
\text { нижний слой } 5 \text { см [7.3 km from } \\
\mathrm{S} . \mathrm{V} . \text { - Balkaria, } 20 \mathrm{~m} \text { from the } \\
\text { shore, the woods, } \\
\text { top. layer - } 0-5 \mathrm{~cm} \text {, } \\
\text { the bottom layer is } 5 \mathrm{~cm}]\end{array}$ & $\begin{array}{l}6,90 \\
6,10\end{array}$ & $\begin{array}{c}78,2 \\
112\end{array}$ & $\begin{array}{l}16,6 \\
30,1\end{array}$ & $\begin{array}{l}54,2 \\
20,3\end{array}$ & $\begin{array}{l}3,55 \\
1,78\end{array}$ \\
\hline 7. & $\begin{array}{l}5,7 \text { км от с. В.- Балкария, } 50 \text { м } \\
\text { от берега, лес, } \\
\text { верхн. слой - } 0-8 \text { см. } \\
\text { нижний слой } 8 \text { см }[5.7 \mathrm{~km} \text { from } \\
\mathrm{S} . \mathrm{V} .- \text { Balkaria, } 50 \mathrm{~m} \text { from the } \\
\text { shore, the woods, } \\
\text { top. layer } 0-8 \mathrm{~cm} \\
\text { the bottom layer is } 8 \mathrm{~cm}]\end{array}$ & $\begin{array}{l}6,45 \\
6,35\end{array}$ & $\begin{array}{c}80,3 \\
121\end{array}$ & $\begin{array}{l}17,9 \\
32,1\end{array}$ & $\begin{array}{l}60,9 \\
12,5\end{array}$ & $\begin{array}{l}2,13 \\
2,13\end{array}$ \\
\hline 8. & $\begin{array}{l}3,7 \text { км от с. В.- Балкария, } 30 \text { м } \\
\text { от берега, луг, } \\
\text { верхн. слой - } 0-10 \mathrm{cm.} \\
\text { нижний слой } 10 \mathrm{~cm} \mathrm{[3.7} \mathrm{km} \\
\text { from S. V. - Balkaria, } 30 \mathrm{~m} \text { from } \\
\text { the shore, the meadow, } \\
\text { top. the layer } 0-10 \mathrm{~cm} \\
\text { the lower layer } 10 \mathrm{~cm}]\end{array}$ & $\begin{array}{l}6,50 \\
7,25\end{array}$ & $\begin{array}{l}42 \\
36\end{array}$ & $\begin{array}{l}4,72 \\
8,95\end{array}$ & $\begin{array}{l}52,1 \\
28,5\end{array}$ & $\begin{array}{l}2,13 \\
1,78\end{array}$ \\
\hline
\end{tabular}


тов в нижнем горизонте почти в 2 раза. Максимально высокая концентрация серосодержащего компонента почвы, равная 68,16 мг/кг, отмечалась в слое 0-3 см лесной почвы, где и наблюдается самая низкая концентрация водородных ионов $(\mathrm{pH}=5,55)$. В целом, сульфаты изменялись от 50,4 до 68,19 мг/кг в горизонте А и от 2,88 до 38,4 мг/кг в горизонте В. Сера выполняет роль элемента питания и выявленные ее концентрации в почвах достаточны для функционирования жизненно важных процессов для растительности.

Хлориды. Изменяющиеся природные условия могут приводить как к уменьшению скорости потери питательных веществ, так и к их возрастанию. Это относится к хлору. В последнее время хлоридная составляющая атмосферных осадков на территории республики заметно выросла, что вероятнее связано с эмиссией хлористых соединений. Увеличение его концентрации в весенне-летний период вносит свою долю в загрязнение почвы. Одним из источников поступления хлористых соединений в атмосферу являются газ и жидкое топливо. Надо отметить, что район исследования находится недалеко от села Верхняя Балкария, где местное население использует жидкое и газообразное топливо в различных целях, а как известно отработанные газы поступают в атмосферу, где и могут скапливаться, а затем с осадками возвращаться на поверхность земли. Также отметим, что на содержание хлоридов в почвах исследуемой территории оказывают влияние множество минеральных источников. Химический анализ почв во всех пунктах на содержание хлоридов показал, что почвенная концентрация хлора достаточно высокая в верхних слоях почвы и составляет 15,9831,95 мг/кг, меньше во втором слое в луговых почвах (3,9-6,4 мг/кг). В горизонте В лесной почвы его содержание увеличилось почти в 3 раза (от 30,2 до 88,75$)$, что говорит о тенденции его накопления в нижнем слое. В пробах осеннего отбора содержание ионов хлора было невысоким. Полученные данные по хлору напрямую указывают на наметившуюся тенденцию к загрязнению почв ионами хлора, особенно лесную.

\section{ЗАКЛЮЧЕНИЕ}

Полученные в результате проведенных исследований данные могут послужить базовым материалом для организации долговременного фонового почвенного мониторинга на ключевых участках. В будущем представляется целесообразным продолжение исследований в заповеднике, расши- рив их на более широкий спектр почвообразующих пород и растительных сообществ.

Систематический сбор данных о свойствах почв позволит использовать банк данных для анализа общих закономерностей и региональных особенностей структуры и функционирования охраняемых.

\section{СПИСОК ЛИТЕРАТУРЫ}

1. Ромашкевич А.И. Горное почвообразование и геоморфологические процессы. Москва, Наука, 1996. $126 \mathrm{c}$.

2. Manfred Stahli. Hydrological significance of soil frost for pre-alpine areas. Journal of Hydrology. 2017, no. 4, pp. 90-102.

3. Jan Pietrona, Sergey R. Chalov, Aleksandra S. Chalova, Alexey V. Alekseenko, Jerker Jarsjo. Extreme spatial variability in riverine sediment load inputs due to soil loss in surface mining areas of the Lake Baikal basin. CATENA. 2017, v. 152, pp. 82-93.

4. Susana Fernandez, Tomas Cotos-Yanezb, Javier Roca-Pardinasb, Celestino Ordonez. Application to rough mountain areas in Northwest Spain. Geographically Weighted Principal Components Analysis to assess diffuse pollution sources of soil heavy metal. Geoderma, 2016, v. 200-201, pp. 9-17.

5. J.G. Nelson National parks and protected areas, national conservation strategies and sustainable development. Geoforum, 1987, no. 3, pp. 291-319.

6. J.M. Foggin. Reference Module in Earth Systems and Environmental Sciences. [Conservation Issues: Mountain Ecosystems]. 2016, pp. 1-14;

7. Marta Galvagno, Georg Wohlfahrt, Edoardo Cremonese, Gianluca Filippa, Mirco Migliavacca, Umberto Mora di Cella, Eva van Gorsel Contribution of advection to nighttime ecosystem respiration at a mountain grassland in complex terrain. Agricultural and Forest Meteorology. 2017, pp. 270-281.

8. Corey R. Lawrence, Richard L. Reynolds, Michael E. Ketterer, Jason C. Neff Aeolian controls of soil geochemistry and weathering fluxes in high-elevation ecosystems of the Rocky Mountains, Colorado. Geochimica ET Cosmochimica Acta. 2013, pp. 27-46.

\section{REFERENCES}

1. Romashkevich A.I. Gornoe pochvoobrazovanie $i$ geomorfologicheskie protsessy [Mountain soil formation and geomorphological processes]. Moscow, Nauka, 1996. $126 \mathrm{p}$.

2. Manfred Stahli. Hydrological significance of soil frost for pre-alpine areas. Journal of Hydrology, 2017, no. 4, pp 90-102.

3. Jan Pietrona, Sergey R. Chalov, Aleksandra S. Chalova, Alexey V. Alekseenko, Jerker Jarsjo. Extreme spatial variability in riverine sediment load inputs due to soil loss in surface mining areas of the Lake Baikal basin. CATENA, 2017 , v. 152 , pp. $82-93$. 
4. Susana Fernandez, Tomas Cotos-Yanezb, Javier Roca-Pardinasb, Celestino Ordonez. Application to rough mountain areas in Northwest Spain. Geographically Weighted Principal Components Analysis to assess diffuse pollution sources of soil heavy metal. Geoderma, 2016, v. 200201, pp. 9-17.

5. J. G. Nelson National parks and protected areas, national conservation strategies and sustainable development. Geoforum, 1987, no 3, pp. 291-319.

6. J.M. Foggin. Reference Module in Earth Systems and Environmental Sciences. [Conservation Issues: Mountain Ecosystems]. 2016, pp. 1-14.

\section{КОНФЛИКТ ИНТЕРЕСОВ}

Авторы декларируют отсутствие явных и потенциальных конфликтов интересов, связанных с публикацией настоящей статьи.

Газаев Хаджи-Мурат Мухтарович директор Кабардино-Балкарского высокогорного государственного природного заповедника, Кабардино-Балкарская республика, п. Кашхатау, Российская Федерация, E-mail: muktargazaev@mail.ru

Мурзамуратова Людмила Сайрамбаевна младший научный сотрудник Кабардино-Балкарского высокогорного государственного природного заповедника, Кабардино-Балкарская республика, п. Кашхатау, Российская Федерация,

ORCID: https://orcid.org/0000-0001-5898-2412, E-mail: Luki-786.90@mail.ru

Атабиева Фатимат Адраевна

кандидат химических наук, ведущий научный сотрудник Кабардино-Балкарского высокогорного государственного природного заповедника, Кабардино-Балкарская республика, п. Кашхатау, Российская Федерация, E-mail: atabieva55@mail.ru

Жинжакова Лилия Зуберовна

старший научный сотрудник Высокогорного геофизического института, Кабардино-Балкарская республика, г. Нальчик, Российская Федерация
7. Marta Galvagno, Georg Wohlfahrt, Edoardo Cremonese, Gianluca Filippa, Mirco Migliavacca, Umberto Mora di Cella, Eva van Gorsel Contribution of advection to nighttime ecosystem respiration at a mountain grassland in complex terrain. Agricultural and Forest Meteorology, 2017, pp. 270-281.

8. Corey R. Lawrence, Richard L. Reynolds, Michael E. Ketterer, Jason C. Neff Aeolian controls of soil geochemistry and weathering fluxes in high-elevation ecosystems of the Rocky Mountains, Colorado. Geochimica ET Cosmochimica Acta, 2013, pp. 27-46.

\section{CONFLICT OF INTEREST}

The authors declare no information of obvious and potential conflicts of interest related to the publication of this article.

Hadji-Murat M. Gazaev

Director at the Kabardino-Balkar High-Mountain State Nature Reserve, Kabardino-Balkar Republic, Kashhatau, Russian Federation, E-mail: muktargazaev@mail.ru

Lyudmila S. Murzamuratova

junior researcher at the Kabardino-Balkar High-Mountain State Nature Reserve, Kabardino-Balkar Republic, Kashhatau, Russian Federation, ORCID:

https://orcid.org/0000-0001-5898-2412, E-mail:

Luki-786.90@mail.ru

Fatmatu A. Atabieva

Cand. Sci. (Chem.), leading researcher at the KabardinoBalkar High-Mountain State Nature Reserve, KabardinoBalkar Republic, Kashhatau, Russian Federation, E-mail: atabieva55@mail.ru

Lily Z. Jinjakova

Senior researcher at the High-Mountain Geophysical Institute, Kabardino-Balkarian Republic, Nalchik, Russian Federation 